\title{
PENINGKATAN PEMAHAMAN KONSEP NILAI TEMPAT BILANGAN MELALUI MEDIA GELAS WARNA PADA SISWA KELAS I SDN PURWANTORO 2 MALANG
}

\author{
Farhatul Hakiki $^{1}$, Dyah Worowirastri Ekowati ${ }^{2}$, dan Wiwik Susintowati ${ }^{3}$ \\ PPG PGSD FKIP Universitas Muhammadiyah Malang ${ }^{1,2}$, SDN Purwantoro 2 Malang $^{3}$ \\ Email: farhatulhakiki@gmail.com ${ }^{1}$; dyah_umm@yahoo.com ${ }^{2}$; purwantorodua@yahoo.com ${ }^{3}$
}

\section{Info Artikel}

SejarahArtikel:

Diterima 27 Maret 2019

Direvisi 1 Juni 2019

Disetujui 3 Juni 2019

\section{Keywords:}

concept understanding, number place value, color glass

Abstract

This study aims to determine the increase in understanding of the concept of place number values in class $1 B$ students by using color glass media at SDN Purwantoro 2 Malang. This study uses qualitative research and the type of research is classroom action research. The data sources are class 1 of SDN Purwantoro 2 Malang, totaling 25 students and class $1 B$ teachers. The data obtained in the form of understanding concept of place number value seen from the value of student learning outcomes. Data collection techniques used were observation, interviews, tests, and documentation. Time of study January to February 2019. This study was conducted in 2 cycles and each cycle had 2 meetings. Each cycle has 4 stages, namely preparation, implementation, observation, and reflection. The application of color glass media increases the understanding of the concept of place number values in class $1 B$ students at SDN Purwantoro 2 Malang. It is shown that understanding the concept of place number values seen from student learning outcomes in the pre-cycle average value of students at 63.2 increased to 66.6 in the first cycle and 81.6 in the second cycle with the percentage of completeness from $36 \%$ in the pre-cycle to $56 \%$ in the cycle I and $80 \%$ in cycle II.
\end{abstract}

\begin{abstract}
Abstrak
Penelitian ini bertujuan untuk mengetahui peningkatan pemahaman konsep nilai tempat bilangan pada siswa kelas 1B dengan menggunakan media gelas warna di SDN Purwantoro 2 Malang. Penelitian ini menggunakan penelitian kualitatif serta jenis penelitiannya adalah penelitian tindaka nkelas. Sumber datanya yaitu kelas1-B SDN Purwantoro 2 Malang yang berjumlah 25 siswa serta guru kelas 1-B. Data yang didapatkan berupa pemahaman konsep nilai tempat bilangan yang dilihat dari nilai hasil belajar siswa. Teknik pengumpulan data yang digunakan yaitu observasi, wawancara, tes dan dokumentasi. Waktu penelitian pada bulan Januari sampai Februari 2019. Penelitian ini dilaksanakan dalam 2 siklus dan tiap siklus ada 2 pertemuan. Tiap siklus ada 4 tahapan yaitu persiapan, pelaksanaan, observasi dan refleksi. Penerapan media gelas warna meningkatkan pemahaman konsep nilai tempat bilangan pada siswa kelas 1-B di SDN Purwantoro 2 Malang. Hal ini ditunjukkan bahwa pemahaman konsep nilai tempat bilangan yang dilihat dari hasil belajar siswa pada pra siklus nilai rata-rata siswa sebesar 63.2 meningkat menjadi 66.6 di siklus I dan 81.6 pada siklus II dengan persentase ketuntasan dari $36 \%$ pada pra siklus menjadi $56 \%$ pada siklus I dan $80 \%$ pada siklus II.
\end{abstract}


Hakiki, Farhatul, dkk

PENINGKATAN PEMAHAMAN KONSEP NILAI TEMPAT BILANGAN MELALUI ...

REFLEKSI EDUKATIKA : Jurnal Ilmiah Kependidikan, Volume 9, Nomor 2, Juni 2019, hlm 223-228

\section{PENDAHULUAN}

Matematika merupakan salah satu mata pelajaran yang sangat penting karena dapat membantu manusia dalam menyelesaikan permasalahan sehari-hari. Hal tersebut sesuai dengan pendapat Nugraheni (2017) yang menyatakan bahwa di dalam matematika banyak membahas tentang fakta, hubunganhubungannya, serta problem yang melibatkan lingkup ruang dan waktu. Oleh karena itu, matematika dapat membantu manusia menafsirkan secara eksak semua ide maupun gagasan serta kesimpulan oleh manusia itu sendiri.

Matematika merupakan mata pelajaran yang membutuhkan beberapa kemampuan untuk menguasainya yaitu pemahaman, pemikiran, dan penalaran (Prasetyo, 2016: 2) sehingga seringkali peserta didik menganggap bahwa pelajaran matematika itu sangat sulit untuk dipahami. Hal tersebut dikarenakan peserta didik memiliki kemampuan dan karakter yang berbeda satu sama lain. Seringkali ditemui ada beberapa peserta didik yang memiliki kemampuan kognitif tinggi sehingga dapat cepat memahami suatu pembelajaran, sedangkan ada juga yang kemampuan kognitifnya masih rendah sehingga mengalami kesulitan dalam memahami suatu pembelajaran.

Dalam proses belajar mengajar siswa kurang aktif ketika mengikuti pembelajaran. Hal ini ditunjukkan ketika guru menjelaskan materi banyaksiswa yang tiduran diatas bangku dengan tangan diselonjorkan dan kepalanya menunduk, jalan-jalan mengganggu temannya, dan juga menggambar di meja. Ketika guru memberikan tugas siswa sering mengeluh dengan alas an capek menulis. Namun guru tetap memberikan tugas tersebut untuk mengukur sejauhmana pemahaman siswa terhadap materi yang telah disampaikan.

Selama proses pembelajaran, peserta didik tidak memahami konsep nilai tempat bilangan disebabkan beberapa halyaitucara guru dalam menyampaikan materi yang masih kaku atau monoton. Guru hanya menjelaskan materi di papan tulis kemudian memberikan contoh soal. Setelah itu, peserta didik mengerjakan latihan soal yang diberikan oleh guru kemudian di akhir pembelajaran guru memberikan ulasan terkait soal yang telah dikerjakan. Metode seperti itu dan tidak adanya media cenderung membuat peserta didik kurang tertarik dengan pembelajaran dan tidak memahami konsep yang diajarkanoleh guru.

Salah satu karakteristik yang dimiliki matematika adalah mempunyai obyek yang sifatnya masih abstrak atau tidak konkret. Obyek matematika yang sifatnya abstrak itulah yang membuat pembelajaran matematika itu sendiri dianggap sulit dan tidak mudah dipahami tanpa adanya media pembelajaran (Sumarni: 2016). Suatu pembelajaran akan lebih bermakna apabila ada media pembelajaran. Menurut Novita (2014: 5) mengemukakan bahwa pengalaman belajar peserta didik yang penting dan diperlukan dalam membangun suatu pemahaman konsep tersendiri terlebih lagi apabila didukung dengan adanya media pembelajaran dijadikan alat bantu yang berfungsi mengkonkretkan materi matematika yang masih bersifat abstrak. Peserta didik Sekolah Dasar pada dasarnya perkembangan intelektualnya dalam tahap operasional konkret (Piaget dalam Novita, 2014: 5) yaitu cara berfikirnya masih didasarkan atas manipulasi fisik dari obyek-obyek. Pemahaman konsep didasarkan pada intelektual peserta didik akan dapat dipahami apabila melibatkan media pembelajaran atau alat peraga yang konkret yaitu bentuknya nyata, dapat diotak-atik oleh peserta didik serta masih berkaitan dengan kehidupan peserta didik sehingga suatu pembelajaran tersebut akan lebih bermakna. Pemahaman tersebut akan menjadi ingatan jangka panjang karena peserta didik membangun sendiri pengetahuannya.

Mengatasi permasalahan tersebut, dapat menggunakan media pembelajaran yang menarik. Suatu media pembelajaran dapat diterapkan dengan menyesuaikan karakteristik peserta didik sehingga akan menjadikan pembelajaran itu menarik dan aktif. Melalui media pembelajaran yang menarik tersebut akan memberikan kesempatan maksimal kepada anak untuk mampu membangun sendiri pengetahuannya dalam memahami konsep nilai tempat bilangan dengan mengotak atik media secara langsung. Media pembelajaran yang dapat digunakan untuk memahamkan konsep nilai tempat bilangan yaitu media gelas warna. Media gelas warna tersebut digunakan untuk membantu siswa dalam memahami nilai tempat puluhan dan nilai tempat satuan. Masing-masing nilai tempat memiliki warna yang berbeda sehingga memudahkan peserta didik dalam memahami konsep tersebut. Nilai tempat puluhan menggunakan gelas warna merah sedangkan nilai tempat satuan menggunakan gelas warna kuning.

\section{METODE PENELITIAN}

Jenis penelitian adalah penelitian tindakan kelas (PTK) menggunakan model dari Kemmis $\&$ Mc. Taggart yang terdiri dari empat komponen 
Hakiki, Farhatul, dkk

PENINGKATAN PEMAHAMAN KONSEP NILAI TEMPAT BILANGAN MELALUI ...

REFLEKSI EDUKATIKA : Jurnal Ilmiah Kependidikan, Volume 9, Nomor 2, Juni 2019, hlm 223-228

yaitu planning (perencanaan), acting (tindakan), observing (pengamatan), dan reflecting (refleksi).

Selama penelitian berlangsung, peneliti berperan sebagai pelaksana PTK dan pengamat penelitian yang berkolaborasi dengan guru kelas 1 SDN Purwantoro 2 Malang. Peneliti melakukan tindakan sesuai dengan rencana yang telah dibuat secara cermat dan mencacat semua hasil yang diperoleh selama pengamatan dalam tindakan. Peneliti menganalisis data tersebut dan membuat kesimpulan terkait pemahaman konsep nilai tempat bilangan dengan menggunakan media gelas warna tersebut mengalami peningkatan atau tidak. Peneliti dan guru saling berdiskusi terkait refleksi proses pembelajaran yang telah dilakukan

Populasi penelitian ini adalah peserta didik kelas I-B yang berjumlah orang, terdiri dari 12 peserta didik perempuan dan 13peserta didik laki-laki. Data yang dikumpulkan dalam penelitian ini adalah pemahaman konsep nilai tempat bilangan pada siswa kelas I-B SDN Purwantoro 2 Malang setelah mengerjakan soal evaluasi dari kegiatan pembelajaran dengan menggunakan media gelas warna.

Instrumen yang digunakan adalah lembar observasi, soal tes, dan lembar wawancara. Prosedur PTK meliputi beberapa siklus, sesuai dengan tingkat permasalahan yang di pecahkan dan kondisi yang ditingkatkan. Penelitian dilakukan selama 2 siklus dengan pertimbangan apabila peningkatan yang terjadi tergolong pada kategori baik. Apabila hasil belum memuaskan, peneliti menambah siklus lagi dst. Masingmasing siklus dilakukan pada 2 kali pertemuan. Hal tersebut dilakukan karena nantinya masingmasing siklus akan menggunakan indikator yang berbeda sehingga untuk memaksimalkan ketercapaian tujuan pembelajaran.

Penelitian Tindakan Kelas ini dilaksanakan pada tanggal 14-24 Januari 2019 yang dimulai dari kegiatan prasiklus kemudina dilanjutkan siklus I hingga siklus II. Penelitian ini berlangsung 2 siklus dengan masing-masing siklus dilaksanakan 2 kali pertemuan. Setiap pertemuan pada pembelajaran dilangsungkan selama 5 jam pelajaran yaitu 175 menit di kelas IB SDN Purwantoro 2 Malang.

Proses pembelajaran pada kegiatan prasiklus dilaksanakan pada tanggal 14 Januari 2019. Kegiatan tersebut dilakukan melalui observasi yang dilakukan ketika pembelajaran tentang nilai tempat bilangan yang dilakukan oleh guru tanpa menggunakan media. Hasil belajar didapatkan dari nilai evaluasi yang telah dikerjakan oleh siswa di akhir pembelajaran.
Pada kegiatan prasiklus masih banyak siswa yang belum tuntas KKM yaitu 75,00. Siswa yang tuntas pada prasiklus ada 9 siswa dari 25 siswa.

Siklus I dilaksanakan pada hari Rabu 16 Januari 2019 dan hari Kamis 17 Januari 2019. Proses pembelajaran pada siklus I mempelajari tentang nilai tempat bilangan puluhan dan satuan.

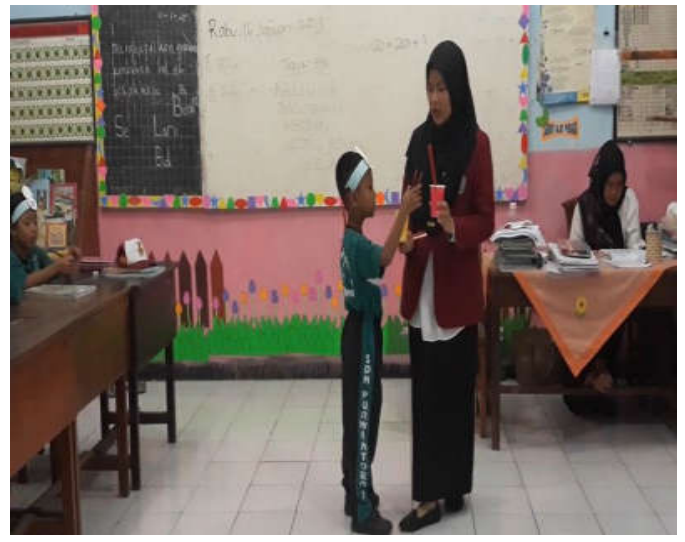

Gambar 1. Penggunaan media gelas warna pada kegiatan pembelajaran.

Berdasarkan gambar 1 diatas, dapat diketahui bahwa peneliti menggunakan media gelas warna merah dan kuning serta sedotan untuk membantu siswa memudahkan dalam membedakan nilai tempat bilangan puluhan dan satuan. Pada siklus I yang mengalami ketuntasan ada 14 siswa dari 25 siswa. Jumlah ketuntasan pada siklus I masih belum memenuhi kriteria ketuntasan sehingga dilanjutkan dengan pelaksanaan siklus II. Kegiatan siklus II dilaksanakan pada hari Rabu 23 Januari 2019 dan hari Kamis 24 Januari 2019.

Pada pelaksanaan siklus II, indikator yang digunakan lebih tinggi dibandingkan siklus I. Pada siklus II tidak hanya pada pemahaman konsep nilai tempat bilangan tetapi juga membandingkan dua bilangan yang mana antara dua bilangan tersebut bernilai lebih banyak atau lebih sedikit dibandingkan bilangan yang lain. Hasil belajar siswa pada siklus II sudah banyak peningkatan. Hal tersebut dilihat dari ketuntasan yang mencapai 20 siswa dari 25 siswa.

Berdasarkan hasil penelitian yang telah diperoleh, dapat diketahui bahwa pemahaman konsep nilai tempat bilangan pada siswa mengalami peningkatan dimulai dari kegiatan prasiklus hingga siklus II. Peningkatan yang terjadi dapat dilihat dari nilai rata-rata hasil belajar siswa dan presentase ketuntasan siswa yang dapat dijabarkan pada tabel dibawah ini. 
Hakiki, Farhatul, dkk

PENINGKATAN PEMAHAMAN KONSEP NILAI TEMPAT BILANGAN MELALUI ...

REFLEKSI EDUKATIKA : Jurnal Ilmiah Kependidikan, Volume 9, Nomor 2, Juni 2019, hlm 223-228

Tabel 1. Peningkatan rata-rata nilai pemahaman konsep nilai tempat bilangan.

\begin{tabular}{lccc}
\hline \multicolumn{1}{c}{ Aspek } & $\begin{array}{c}\text { Pra } \\
\text { Siklus }\end{array}$ & Siklus I & Siklus II \\
\hline $\begin{array}{l}\text { Nilai Rata-Rata } \\
\text { Jumlah }\end{array}$ & 63.2 & 66.6 & 81.6 \\
$\begin{array}{l}\text { Ketuntasan } \\
\text { Persentase }\end{array}$ & 9 & 14 & 20 \\
Ketuntasan & $36 \%$ & $56 \%$ & $80 \%$ \\
\hline
\end{tabular}

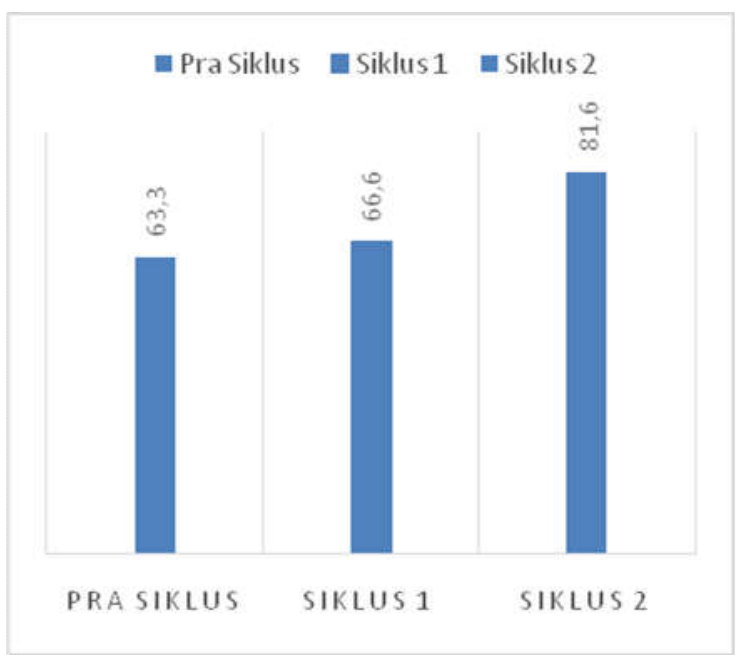

Diagram 1. Peningkatan rata-rata nilai siswa

Berdasarkan tabel 1 dan diagram 1 di atas, dapat diketahui bahwa terjadi peningkatan pada kegiatan prasiklus ke siklus I dan peningkatan dari siklus I ke siklus II. Peningkatan nilai ratarata yang terjadi pada kegiatan prasiklus yaitu 63.2 meningkat menjadi 66.6 pada siklus I. Sedangkan dari siklus I ke siklus II mengalami peningkatan yang cukup tinggi yaitu dari 66.6 menjadi 81.6. Jumlah ketuntasannya pada prasiklus sebanyak 9 siswa mengalami peningkatan menjadi 14 siswa pada siklus I dan 20 siswa pada kegiatan siklus II. Persentase ketuntasan yang terjadi pada kegiatan prasiklus yaitu 36\% meningkat menjadi 56\% pada siklus I. Peningkatan yang teradi sebesar $20 \%$. Pada siklus I menuju siklus II mengalami peningkatan persentase ketuntasan yang cukup tingi yaitu sebesar 24\% dari 56\% menjadi $80 \%$.

Peningkatan yang terjadi pada kegiatan prasiklus menuju siklus I bisa dikatakan tidak terlalu tinggi atau banyak dikarenakan kemampuan intelektual anak yang memang rendah dan juga kurangnya motivasi belajar. Pada kemampuan intelektual anak itu sendiri terdapat beberapa kondisi yang mempengaruhi kapasitas intelektual anak, diantaranya yaitu kondisi fisik, motivasi dan keluarga. Hal tersebut sesuai dengan pendapat Rivaie (2011) yang mengatakan bahwa kondisi yang mempengaruhi kapasitas intelektual anak adalah pola kepribadian, tingkat emosi, motivasi, pengalaman awal dalam keluarga, pendidikan, penggunaan kapasitas intelektual, dan kondisi fisik anak.

Pada proses pembelajaran, sebagian besar siswa memiliki minat sehingga mampu berkonsentrasi dan mengikuti pembelajaran dengan baik. Namun ada juga beberapa siswa yang tidak berminat mengikuti pembelajaran sehingga kurang memperhatikan penjelasan guru dan mendapatkan nilai yang rendah. Oleh karena itu, minat anak sangat diperlukan demi terwujudnya suatu pembelajaran yang bermakana. Menurut Anam (2015) berpendapat bahwa minat belajar sangat dibutuhkan dalam segala hal, terutama dalam proses belajar siswa. Minat siswa selain untuk memusatkan pikiran, juga mampu menumbuhkan rasa gembira ketika belajar. Kegembiraan tersebut akan memperbesar daya kemampuan belajar anak dan membantunya lebih mengingat apa yang telah dipelajarinya.

Pada siklus I, siswa juga merasa tertarik karena adanya media pembelajaran yang belum pernah mereka gunakan. Media yang digunakan adalah gelas warna dan sedotan. Adanya media pembelajaran sangat mempengaruhi motivasi belajar siswa sehingga siswa akan menjadi tertarik dan semangat. Selain itu, pembelajaran akan berlangsung lebih efektif. Hal tersebut sesuai dengan pendapat Sapartien (2016) yang menyatakan bahwa pembelajaran di sekolah dasar akan dapat berlangsung lebih kreatif, efektif, dan menyenangkan apabila memanfaatkan berbgai macam metode maupun media pembelajaran. Hal tersebut juga sesuai dengan pendapat Musakkir (2015) yang menyatakan bahwa pembelajaran matematika sebaiknya dimulai dengan mengenalkan suatu masalah yang disesuaikan dengan situasi siswa serta menggunakan media supaya pembelajaran tersebut menarik perhatian siswa dan lebih interaktif antara siswa dan guru sehingga pembelajaran menjadi lebih efektif.

Penggunaan media juga sangat membantu dalam mengkonkretkan suatu konsep yang mulanya masih abstrak. Hal tersebut sesuai dengan karakeristik peserta didik Sekolah Dasar yang pada dasarnya perkembangan intelektualnya dalam tahap operasional konkret (Piaget dalam Novita, 2014: 5) yaitu cara berfikirnya masih didasarkan atas manipulasi fisik dari obyek-obyek. Sedangkan menurut Desstya (2015) menyatakan bahwa anak sekolah 
Hakiki, Farhatul, dkk

PENINGKATAN PEMAHAMAN KONSEP NILAI TEMPAT BILANGAN MELALUI ...

REFLEKSI EDUKATIKA : Jurnal Ilmiah Kependidikan, Volume 9, Nomor 2, Juni 2019, hlm 223-228

dasar masih berfikir berdasarkan pengalaman nyata atau konkret. Pengembangan kemampuan inelektual anak usia sekolah dasar sangat membutuhkan benda-benda yang konkret. Siswa secara langsung mengotak-atik benda konkret sehingga lebih nyata dan siswa mengalaminya secara langsung. Media yang konkrit seperti gelas warna tersebut membantu menjadikan konsep-konsep yang mulanya abstrak menjadi konsep konkrit yang mudah dipahami, menyenangkan, menarik perhatian siswa, meningkatkan motivasi belajar siswa serta membantu siswa memiliki ingatan jangka panjang karena pengalamannya selama pembelajaran (Sarwanto, 2016).

Penggunaan media yang menarik yang sesuai dengan perkembangan anak sebagai peragaan dalam proses belajar mengajar akan sangat membantu dalam memahamkan konsep matematika (Sarwanto, 2016: 4-5). Media gelas warna adalah media permainan, mudah membuatnya, bahan-bahan yang digunakan mudah ditemukan dan harganya juga murah. Kelebihan dari media gelas warna ini diantaranya dirancang untuk bisa menjadikan konsep yang abstrak menjadi konkret, menyenangkan, menarik perhatian siswa, membantu ingatan siswa terhadap konsep-konsep karena pembelajarannya dengan pendekatan permainan. Penggunaan media gelas warna akan mempermudah siswa memahami konsep nilai tempat bilangan adalah media permainan yang sangat mudah digunakan.

Peningkatan dari siklus I ke siklus II terjadi cukup tinggi dikarenakan memang sebagian besar siswa sudah memahami konsep nilai tempat bilangan sehingga siswa semakin tertarik dengan penggunaan media gelas warna yang disiapkan peneliti. Siswa juga lebih aktif selama pembelajaran. Pembelajaran pada siklus II yaitu membandingkan besar nilai suatu bilangan sehingga siswa tertarik karena sedikit berbeda dengan pembelajaran siklus I meskipun tetap menggunakan media yang sama.

Peningkatan yang terjadi bukan hanya pada pemahaman konsep nilai tempat bilangan saja tetapi juga pada keaktifan siswa selama kegiatan pembelajaran. Peneliti telah memahami karakteristik siswa sebelum pelaksanaan kegiatan pembelajaran sehingga mampu menentukan jenis kegiatan yang bisa membuat siswa lebih aktif. Hal tersebut sesuai dengan pendapat Alfin (2015) yang enyatakan bahwa guru akan sangat terbantu dalam menciptakan suatu program pembelajaran yang efisian, efektif, dan menarik apabila lebih seksama dalam memperhatikan karakteristik umum siswa. Selama pembelajaran siswa lebih aktif karena adanya media gelas warna yang menarik bagi siswa. Siswa aktif tidak hanya ketika pembelajaran secara klasikal tetapi juga ketika kegiatan diskusi berlangsung. Pembelajaran secara klasikal terlihat sangat efektif karena siswa aktif semua dengan mengangkat tangan untuk berebut maju ke depan menentukan nilai tempat bilangan yang bilangannya telah ditentukan oleh peneliti. Selama diskusipun siswa aktif berpendapat dengan kelompoknya. Siswa yang telah paham mengajari temannya yang masih belum memahami nilai tempat bilangan sehingga kegiatan diskusi berlangsung dengan baik.

Kegiatan pembelajaran dalam meningkatkan pemahaman konsep nilai tempat bilangan dengan menggunakan media gelas warna tidak hanya meningkatkan hasil belajar siswa saja tetapi juga meningkatkan aktivitas guru dan aktivitas siswa selama proses pembelajaran. Bukan hanya peningkatan hasil belajar saja yang penting tetapi nilai proses juga sangat penting sebagai pendukung selama proses belajar mengajar berangsung. Aktivitas siswa dan aktivitas guru juga mengalami peningkatan yang semakin baik. Hal tersebut ditunjukkan pada kegiatan pra siklus siklus I dan siklus II yang mengalami peningkatan terus menerus.

\section{SIMPULAN}

Berdasarkan hasil penelitian dan pembahasan yang telah diuraikan diatas, maka dapat disimpulkan bahwa penggunaan media gelas warna dapat meningkatkan pemahaman konsep nilai tempat bilangan pada siswa kelas 1B SDN Purwantoro 2 Malang. Peningkatan tersebut dapat dilihat pada rata-rata hasil belajar siswa di kegiatan prasiklus yang hanya mencapai 63.2 meningkat menjadi 66.6 pada siklus I. Pada siklus II mengalami peningkatan menjadi 81.6. Persentase ketuntasan pada kegiatan pra siklus sebanyak 36\% meningkat menadi $56 \%$ pada siklus I dan $80 \%$ pada siklus II. Penggunaan media gelas warna tersebut membuat siswa lebih aktif selama kegiatan pembelajaran karena siswa secara langsung mengotak-atik dan memainkan media tersebut.

Bagi guru sebaiknya dalam melaksanakan pembelajaran matematika mengunakan media pembelajaran yang disesuaikan dengan materi yang akan diajarkan. Bagi sekolah juga sebaiknya menyediakan sarana dan prasarana serta fasilitas yang mendukung guna menunjang proses kegiatan pembelajaran agar peserta didik dapat belajar dengan maksimal dan dapat mewujudkan sekolah yang bermutu dan berkualitas. 
Hakiki, Farhatul, dkk

PENINGKATAN PEMAHAMAN KONSEP NILAI TEMPAT BILANGAN MELALUI ...

REFLEKSI EDUKATIKA : Jurnal Ilmiah Kependidikan, Volume 9, Nomor 2, Juni 2019, hlm 223-228

\section{DAFTAR PUSTAKA}

Alfin, Jauharoti. 2015. Analisis Karakteristik Siswa pada Tingkat Sekolah Dasar. Prosiding Halaqoh Nasional dan Seminar Internasional Pendidikan Islam Fakultas Tarbiyah dan Keguruan UIN Sunan Ampel Surabaya, 190-193.

Anam, Khoirul. 2015. Pengaruh Media Pembelajaran Terhadap Minat Belajar Siswa pada Mata Pelajaran PAI di SMP Bani Muqiman Bangkalan. Tadarus Jurnal Pendidikan Islam, 4 (2): 4-8.

Desstya, Anatri. 2015. Penguatan Karakter Siswa Sekolah Dasar Melalui Pembelajaran IPA. Prosiding Seminar Nasional dan Call for Paper, 69-75

Muchith, M. Saekhan. 2008. Pembelajaran Kontekstual. Semarang: Rasail.

Mulyasa. 2013. Praktik Penelitian Tindakan Kelas. Bandung: RemajaRosdakarya.

Musakir. 2015. Pengaruh Pembelajaran dan Motivasi Belajar terhadap Hasil Belajar Matematika Siswa Kelas IV Sekolah Dasar Kabupaten Tanah Tidung. Jurnal Pendidikan Dasar, 6 (5): 36-47

Nugraheni, Nursiwi. 2017. Penerapan Media Komik pada Pembelajaran Matematika di Sekolah Dasar. Jurnal Refleksi Edukatika, 7 (2): 112-117

Novita, Rita, dkk. 2014. Pembelajaran Penjumlahan Pecahan dengan Menggunakan Media Penjumlahan Pecahan Kertas (PENCAK) di Kelas IV Sekolah Dasar. 1 (1): 1-11
Prasetyo, Tri Wahyu Aji. 2016. Penerapan Model Kooperatif Tipe Number Head Together (NHT) dalam Pembelajaran Matematika untuk Meningkatkan Hasil Belajar Siswa kelas SD Negeri 2 Wonocoyo Tahun Pelajaran 2014/201. Skripsi. Salatiga : Universitas Kristen Satya Wacana.

Rivaie, H. Wanto. 2011. Faktor Intelektual yang Menentukan Kepribadian. Jurnal Pendidikan Sosiologi dan Humaniora, 2 (1): 62-73.

Sapartien Retno. 2016. Peningkatan Hasil Belajar Matematika Melalui Media Tabel dengan Powerpoint pada Siswa Sekolah Dasar. Jurnal Refleksi Edukatika, 7 (1): 28-31.

Sarwanto, Endi. 2016. Penggunaan Media Gelas Bilangan dalam Meningkatkan Hasil Belajar Kognitif Matematika pada Siswa Kelas I SD Muhammadiyah Kayen Depok Sleman. Skripsi. Yogyakarta : Program Sarjana Universitas Islam Negeri Sunan Kalijaga.

Sumarni. 2016. Upaya Meningkatkan Kemampuan Berhitung Melalui Penerapan Model Pembelajaran Number Head Together dengan Pemanfaatan Alat Peraga Sederhana Materi Pembagian Siswa Kelas 2. Jurnal Refleksi Edkatika. 7 (1): 62-68.

Sundayana, Rostina. 2015. Media dan Alat Peraga dalam Pembelajaran Matematika. Bandung: Alfabeta. 